\title{
Optimising stocking density for the commercial cultivation of sea urchin
} larvae

Suckling, Coleen; Terrey, David; Davies, Andrew

\section{Aquaculture}

DOI:

10.1016/j.aquaculture.2018.01.022

Published: 01/03/2018

Peer reviewed version

Cyswllt i'r cyhoeddiad / Link to publication

Dyfyniad o'r fersiwn a gyhoeddwyd / Citation for published version (APA):

Suckling, C., Terrey, D., \& Davies, A. (2018). Optimising stocking density for the commercial cultivation of sea urchin larvae. Aquaculture, 488, 96-104.

https://doi.org/10.1016/j.aquaculture.2018.01.022

\footnotetext{
Hawliau Cyffredinol / General rights

Copyright and moral rights for the publications made accessible in the public portal are retained by the authors and/or other copyright owners and it is a condition of accessing publications that users recognise and abide by the legal requirements associated with these rights.

- Users may download and print one copy of any publication from the public portal for the purpose of private study or research.

- You may not further distribute the material or use it for any profit-making activity or commercial gain

- You may freely distribute the URL identifying the publication in the public portal ?
}

Take down policy

If you believe that this document breaches copyright please contact us providing details, and we will remove access to the work immediately and investigate your claim. 
1 Optimising stocking density for the commercial cultivation of sea urchin larvae.

2

3 Coleen C. Suckling ${ }^{1,2 *}$; David Terrey ${ }^{1}$; Andrew J. Davies ${ }^{1,3}$.

4

5 Alumni Avenue, Kingston, RI 02881.USA; Kingston, RI 02881. coleen.suckling@uri.edu

\section{Abstract}

${ }^{1}$ School of Ocean Sciences, Bangor University, Askew Street, Anglesey. LL59 5AB. UK.

${ }^{2}$ Fisheries, Animal and Veterinary Sciences, University of Rhode Island, 134 Woodward Hall, 9 East

${ }^{3}$ Biological Sciences, University of Rhode Island, 120 Flagg Road University of Rhode Island

* Corresponding author: Coleen C. Suckling; Email: coleen.suckling@bangor.ac.uk and

Increased pressure on wild stocks of sea urchins had led to a requirement for aquaculture based production. However, effective and efficient methodologies still remain under development. The effects of stocking density on Psammechinus miliaris and Paracentrotus lividus were investigated in order to evaluate optimum stocking densities for large scale production. Larvae were reared at stocking densities of 1, 2, 3 and 4 larvae $\mathrm{mL}^{-1}$ and the effects on survival, development, abnormality and morphology were recorded. Additional cultures were maintained at a high density of 3 larvae $\mathrm{mL}^{-1}$ and then displaced to a lower density of 1 larvae $\mathrm{mL}^{-1}$ part way through the larval life cycle ('displacement treatment'; day 13), to evaluate whether negative effects of high stocking densities could be mitigated. Responses from each species differed. $P$. miliaris demonstrated the highest growth at 1 larvae $\mathrm{mL}^{-1}$, resulting in larger larval and rudiment sizes by the end of the experiment (day 16). Rearing at 2 larvae $\mathrm{mL}^{-1}$ also demonstrated good growth performance, but only up to day 12. Higher densities of 3 and 4 larvae $\mathrm{mL}^{-}$ ${ }^{1}$ did not affect survival or development, but significantly negatively impacted growth. There was no significant impact on survival, development, and morphology at any of the tested stocking densities for $P$. lividus. However, of note is that $P$. lividus reared at a high density of 4 larvae $\mathrm{mL}^{-1}$ had $25 \%$ lower survival than controls by the end of the experimental period (day 16). Displacement (larvae transferred from 3 to 1 larvae $\mathrm{mL}^{-1}$ on day 13) was effective for both $P$. miliaris and P. lividus with survival and rudiment sizes similar to larvae stocked continuously at low densities of 1 larvae $\mathrm{mL}^{-1}$. Although, $P$. lividus generally performed well at high densities, this demonstrates that displacement approaches could be possible for this species if required. However, of note is that displaced P. lividus had $30 \%$ lower survival than controls by the end of the experimental period (day 16). Therefore, this cultivation 
36 approach may be a generally viable option for large scale cultivation of these species. This study 37 highlights that species responses can be different when reared at differing stocking densities 38 highlighting a need to expand this approach to a wider range of marketable species. It also demonstrates 39 that more efficient means of production (e.g. displacing larval densities part way through the production 40 process) might be possible for some species (e.g. P. miliaris).

41

42 Keywords: aquaculture; echinoderm; echinoculture; market; rearing; shellfish. 43 


\section{Introduction}

Global harvesting of sea urchins has substantially increased in recent decades. Rising from 48,000 tonnes in 1982 to 120,000 tonnes in 1995, this has caused sharp declines of wild stocks as a direct result of overexploitation, with harvesting currently at 75,000 tonnes (Pearce, 2010; Stefánsson et al., 2017). Consequently, there has been an increased effort into the development of successful rearing techniques for a variety of edible species (e.g. Fernandez \& Caltagirone, 1994; de Jong-Westman et al. 1995; Grosjean et al. 1998) with rapid advances in research into intensive culture systems, especially in Europe (Carboni et al. 2014).

Sea urchin larval cultivation techniques are reasonably well established with some studies focussed on optimising methodology, examples include investigating the effects of feed types (Hinegardner, 1969; Fenaux et al. 1985; Leighton et al. 1994; Cook et al. 1998; Kelly et al. 2000; Liu et al. 2007), salinity (Metaxas 1998; George \& Walker 2007), and temperature (Hart \& Scheibling 1988; Sewell \& Young 1999). However, optimum stocking densities for larval cultures have not yet been satisfactorily identified for all species. Experimental studies commonly maintain cultures at 1 larvae $\mathrm{mL}^{-1}$ (e.g. Fenaux et al. 1994; Leighton 1995; Kelly et al. 2000; Liu et al. 2007), but within a commercial setting it would be more economical and efficient to rear larvae at higher densities, as long as larval quality is not compromised. To date there are only two studies which have directly investigated the effect of larval stocking density on echinoid species. Buitrago et al. (2005) assessed the response of larvae of the sea urchin Lytechinus variegatus to extremely low stocking densities (equivalent to 0.25 , 0.50 and 1 larvae $\mathrm{mL}^{-1}$ ). Larval masses reared at a density of 1 larvae $\mathrm{mL}^{-1}$ were $50 \%$ lower than larvae reared at the lower densities of 0.25 and 0.50 larvae $\mathrm{mL}^{-1}$. However, the authors concluded that stocking densities of 1 larvae $\mathrm{mL}^{-1}$ were suitable for cultivation. Azad et al. (2012) used higher stocking densities equivalent to $0.5,1,2$ and 4 larvae $\mathrm{mL}^{-1}$ on Strongylocentrouts purpuratus and concluded that larval survival and growth was greatest when stocked at low densities of $\leq 1$ larvae $\mathrm{mL}^{-1}$ compared to higher densities $\left(>2\right.$ larvae $\left.\mathrm{mL}^{-1}\right)$. These two studies are in agreement, suggesting that an optimal stocking density for sea urchins may be around 1 larvae $\mathrm{mL}^{-1}$, but are based on only two species. It is widely known that responses to different holding conditions can be species specific (e.g. Fujisawa, 1989; Liu \& Chang, 2015). Therefore, more resilient species could display commercially acceptable tolerances, allowing for an intensification of stocking density practices.

Larvae stocked at higher densities will have less relative space per individual and subsequently crowding, competition for space, food and other resources will be more pronounced. These will be exacerbated as the larvae grows and occupies more space (Forsythe et al. 2002). The interaction between conspecifics, competitors and prey can affect growth directly. For example, by affecting food intake, or indirectly, by diverting energy from somatic growth (Forsythe \& Heaukelem, 1987; Siikavuopio, et al. 2007). Overcrowding can also restrict oxygen supply and increase collisions resulting in physical damage (Buitrago et al. 2005; Azad et al. 2010). Subsequently these factors of influence can negatively impact survival, growth and quality in many studied species (e.g. sea 
cucumbers (Li \& Li, 2009), shrimp (Martin et al. 1998) and fish (Paspatis et al. 2003)). Introducing additional feed into systems can alleviate competition but also results in increased waste production, which can introduce dangerous levels of toxins, causing malformation or mortality (Cho et al. 1994; Gomes et al. 2000; Ebeling et al. 2006; McEdward \& Miner, 2007). Some negative effects can largely be mitigated by appropriate cultivation techniques. However, the effects of space limitations caused by high stocking densities cannot, unless these densities are reduced, and this could be implemented part way through the larval development cycle (e.g. from high to low stocking density). During the early stages of larval development larvae are typically small, occupy less space and subsequently may be less prone to damage compared to later developmental stages. No studies have yet investigated this approach on larval quality during cultivation and this approach may enhance sea urchin cultivation success.

The aim of this study was to determine an optimal larval stocking density for sea urchin species where this has not yet been previously assessed. Additionally, larvae reared at high stocking densities during the early stages of larval development were later transferred to lower densities, to determine whether larval survival, growth and development could be improved. In this study, two sea urchin species were investigated, Paracentrotus lividus and Psammechinus miliaris. P. lividus is a wellestablished commercially harvested species with substantial commercial appeal (Bourdouresque \& Verlaque, 2007). Whilst, P. miliaris has demonstrated resilience to future climate change, shows generally positive responses with respect to marketability and is a potential candidate for human consumption (e.g. Kelly et al. 1998; Suckling et al. 2011; 2014a,b).

\section{Materials and methods}

\subsection{Animal collection and maintenance}

Broodstock of $P$. lividus were sourced from laboratory reared animals from Aquaculture Ltd., Ardtoe Marine Laboratory, Ardtoe, Scotland in November 2014. These were transported in coolboxes with aerated seawater from Ardtoe to the Scottish Association for Marine Science aquaria within 4 hours and held in these facilities overnight. The following day the animals were transported under similar conditions to Bangor University's School of Ocean Sciences within 8 hours with a $70 \%$ seawater change every $3^{\text {rd }}$ hour. Broodstock of Psammechinus miliaris were initially sourced from Loch Creran (Symonds et al., 2009), transported under similar protocols and laboratory reared within Bangor

University's School of Ocean Science's aquarium following the methods described by Kelly et al. (2000) and Suckling et al. (2014a,b). These broodstock were maintained at ambient temperature (6.1$16.7^{\circ} \mathrm{C}$ ), salinity (35-36), and ambient photoperiod until the experimental period (June to July 2015). P. miliaris were fed a diet of Laminaria digitata and Mytilus edulis and P. lividus were fed on diets of Laminaria digitata and Palmaria palmata ab libitum.

\subsection{Spawning and larval rearing}



(2000) and Suckling et al. (2014a,b) for rearing of P. miliaris and P. lividus. Spawning was induced

120 by injecting $0.5-1 \mathrm{~mL}$ of $0.5 \mathrm{M} \mathrm{KCl}$ into the haemocoel via the peristomal membrane and individuals spawned into separate $200 \mathrm{~mL}$ jars filled with $1 \mu \mathrm{m}$ filtered and UV sterilised seawater. Using a gamete ratio of 250 t $: 1$ (collected from four females and two males), gametes were mixed in two replicate $8 \mathrm{~L}$ buckets. After 45 minutes fertilisation success was $>92 \%$ and after 24 hours hatching success > $90 \%$ for both species indicating that the eggs used were viable. Successful larvae were then decanted into $12 \mathrm{~L}$ buckets containing gently aerated $1 \mu \mathrm{m}$ filtered and UV sterilised seawater to achieve four stocking density treatments of 1, 2, 3 and 4 larvae $\mathrm{mL}^{-1}$, each with three independent replicates.

Larvae were maintained at an ambient temperature of $\sim 12{ }^{\circ} \mathrm{C}$ and under a photoperiod of 16 hours light and 8 hours dark. Every 2 to 3 days a full water change was carried out by carefully filtering larvae through a $47 \mu \mathrm{m}$ sieve in a water bath to reduce aerial exposure of larvae. The culture buckets were then cleaned with freshwater and a non-abrasive sponge, and larvae washed off the sieve into the relevant culture buckets containing fresh seawater. Total volume of filtered seawater in each treatment were adjusted to ensure that targeted larval densities were maintained throughout the experiment. After the stomach had formed (48 hours after fertilisation) larvae were fed at a rate of 1500, 4500 and 7500 cells $\mathrm{mL}^{-1}$ day $^{-1}$ of the alga Dunaliella tertiolecta (quantified using a haemocytometer) for larval development stages with two, three and four pairs of arms respectively (Kelly et al. 2000). This concentration of feed was scaled with larval density (e.g. cultures of 2 larvae $\mathrm{mL}^{-1}$ received 3000, 9000 and 15000 cells $^{-1} \mathrm{~mL}^{-1} \mathrm{day}^{-1}$ for respective development stages).

\subsection{Larval Survival, development and morphology}

140 Changes in larval survival were calculated by dividing the number of larvae present in the sample by the initial numbers stocked during the start of the experiment and then expressed as a percentage. Each culture was gently agitated to evenly distribute the larval populations and three $5 \mathrm{~mL}$ samples were then taken to assess the density of larvae with a Sedgewick Rafter cell. Larval development was assessed by analysing the proportion of larvae in each stage (stage $1=2$ pairs of arms, stage $2=3$ pairs of arms and stage $3=4$ pairs of arms).

To assess the effects of culture density on morphology of larvae three $25 \mathrm{~mL}$ samples were taken every 2-4 days from each replicate and fixed in $4 \%$ formaldehyde. Fifteen larvae were selected at random for morphological analysis. Under a fume hood, larvae were photographed using a UMCO Useries digital light microscope camera and analysed using the software ImageJ. Photos were scaled using a $1 \mathrm{~mm}$ graticule photographed under the same magnifications. Five morphological measurements were taken from each larva: larval length, body length, body width, post-oral arm length and rudiment length as described by Kelly et al. (2002) and Suckling et al. (2014a). The rudiment, located by the stomach, is where microscopic tube feet and spines appear when the individual is close to metamorphosis for settlement (McEdward \& Herrera, 1999). Larvae with deformities such as irregular 
or additional growth, missing or damaged arms were considered abnormally developed (Okazaki, 1960). Where the skeletal rods protruded from the external membrane of the larvae or unusual thickness/thinness was seen, larvae were considered malnourished (Kelly et al. 2000).

\subsection{Density change trials}

To determine whether the negative responses of highly stocked larvae could be avoided, larvae reared under high stocking density were moved to lower densities part way through larval cultivation. Larvae of P. miliaris and P. lividus were reared, following the protocols outlined above, initially at a density of 3 larvae $\mathrm{mL}^{-1}$. Cultures were then displaced to a lower density of $1 \mathrm{~mL}^{-1}$ on day 13 (when the majority of larvae display 6 pairs of arms) and maintained at this density for the remainder of the experiment (to day 16). These cultures were maintained in the same $12 \mathrm{~L}$ culture buckets to maintain experimental control conditions, and the excess larvae removed from this displacement were discarded due to space limitations. The high stocking density of 3 larvae $\mathrm{mL}^{-1}$ was selected based from preliminary trials that showed that densities of 4 larvae $\mathrm{mL}^{-1}$ resulted in lower larval survival than those reared at 3 larvae $\mathrm{mL}^{-1}$. This displacement treatment (D) was compared directly to low stocking density controls of 1 larvae $\mathrm{mL}^{-1}$.

\subsection{Seawater parameters}

Seawater temperature and salinity was recorded daily using a FRN-3000 digital aquarium thermometer and refractometer respectively. Samples for nitrate analysis were collected before and after each water change and assessed using a Nutrafin nitrate test kit. Significantly higher temperatures were observed for $P$. miliaris compared to $P$. lividus (Kruskal-Wallace, $P<0.001$ ). Therefore, species specific responses were analysed separately in this study. Mean nitrate levels were maintained at 2.9 $\mathrm{mg} \mathrm{L}^{-1}$ across all treatments, a level that is considered unharmful to larvae (Table.1; Gomes et al. 2000).

\subsection{Statistical analysis}

Larval survival and development data were analysed using the SPSS statistical software (IBM; version 20). All data were initially tested for departures from normality using the Shapiro-Wilk test and for homogeneity using the Levene's test. One-way Analysis of Variance (ANOVA) was used to examine water quality parameters, larval survival, morphology, and development data (Sokal \& Rohlf, 1995). Where significant differences occurred $(p<0.05)$, a post hoc Tukey's test was performed. All percentage data were transformed prior to analysis using an arcsine transformation (Dytham, 1999). Where data failed homogeneity testing analysis was carried out using the non-parametric KruskalWallace test (Dytham, 1999). Where type II errors occurred, the means and confidence intervals were graphically analysed to illustrate the data under normal assumptions.

Morphological data were initially tested for normal distribution using the Shapiro-Wilk test and $\log$ transformed followed by regression analyses with larval body length as the independent variable. 
192 Significant relationships between total larval length and body width were tested for. Relationships were 193 then examined using Analysis of Covariance (ANCOVA) (Sokal \& Rohlf, 1995). If the data failed the

194 Levene's test prior to ANCOVA, data were bootstrapped to allow for best estimation of actual results.

\section{3. Results}

1974. 3.1. Stocking density trials

\subsubsection{Survival}

Psammechinus miliaris survival showed a gradual decline across time but no statistically significant differences were identified between stocking densities (day $2: \mathrm{F}_{(4,10)}=1.351, p=0.318$; day 4: $\mathrm{H}_{(4)}=4.633, p=0.327$; day $7: \mathrm{H}_{(4)}=0.645, p=0.567$; day 10: $\mathrm{F}_{(4,10)}=0.140, p=0.964 ;$ day 13: $\mathrm{F}_{(4,10)}$ $=1.082, p=0.416$; day 16: $\mathrm{F}_{(4,10)}=2.025, p=0.167$; Figure 1a). Paracentrotus lividus demonstrated no significant effect of stocking density on survival (day $2: \mathrm{F}_{(4,10)}=0.748, p=0.581$; day $4: \mathrm{F}_{(4,10)}=$ $2.068, p=0.160$; day $7: \mathrm{H}_{(4)}=3.833, p=0.429$; day $10: \mathrm{F}_{(4,10)}=1.082, p=0.416$; day $13: \mathrm{H}_{(4)}=8.315$, $p=0.081$; day $16: \mathrm{H}_{(4)}=0.048, \mathrm{P}=0.048$; Figure 1b).

\subsubsection{Development}

There were no significant differences observed between stocking density treatments for the responses of development stage, number of abnormally developed larvae and percentage of malnourished larvae in P. miliaris across the experimental period ( $p>0.05$; Tables 2 and 3). Differences in development stages and the percentage of malnourished larvae for P. lividus were not affected by stocking density treatments across the experimental period ( $p>0.05$; Tables 2 and 3$)$. However, on day 8 , the percentage of abnormally developed larvae in the control group $\left(1\right.$ larvae $\left.\mathrm{mL}^{-1}\right)$ was significantly higher compared to P. lividus reared at the highest density (4 larvae $\mathrm{mL}^{-1}$; Table 3 ).

\subsubsection{Morphology}

With respect to $P$. miliaris larval lengths and post oral arm lengths, on day 4 (first observation for these parameters) no initial significant differences were observed between the different stocking density treatments (larval length: day 4: $\mathrm{F}_{(4,70)}=1.922, p=0.166$; post oral arm length: $\mathrm{H}_{(4)}=5.012, p$ $=0.286$; Figure $2 \mathrm{a}$ and $\mathrm{c}$ ). However, from day 8 onwards an effect of stocking density became evident. On days 8 and 12 larval lengths and post oral arm lengths for lower stocking densities (1 and 2 larvae $\left.\mathrm{mL}^{-1}\right)$ were significantly larger than higher stocking density reared larvae $\left(3,4 \mathrm{~mL}^{-1}\right.$ larval lengths: day 8: $\mathrm{F}_{(4,70)}=10.782, p<0.001$; day $12: \mathrm{F}_{(4,70)}=25.941, p<0.001$; post oral arm lengths: day 8: $\mathrm{F}_{(4,63)}=$ 19.671, $p<0.001$; day 12: $\mathrm{H}_{(4)}=42.929, p<0.001$; Figure $2 \mathrm{a}$ and c). On day 16 , larvae at $1 \mathrm{~mL}^{-1}$ density had significantly larger larval lengths and post oral arm lengths compared to all other stocking density treatments $\left(2,3\right.$, and $4 \mathrm{~mL}^{-1}$; larval lengths: $\mathrm{F}_{(4,70)}=19.588, p<0.001$; post oral arm lengths: $\mathrm{H}_{(4)}=$ $32.989, p<0.001$; Figure 2a and c). Additionally, larvae stocked at $2 \mathrm{~mL}^{-1}$ had significantly larger larval 
stocked at a low density $\left(1 \mathrm{~mL}^{-1}\right)$ were significantly larger than larvae stocked at the highest density (4 $\mathrm{mL}^{-1} ; \mathrm{F}_{(4,69)}=6.565, p<0.001 ;$ Figure 3a).

With respect to $P$. lividus, no significant effect of stocking density was found on larval lengths or post oral lengths across the experimental period (larval length: day $4: \mathrm{H}_{(4)}=7.965, p=0.093$; day 8: $\mathrm{F}_{(4,70)}=0.318, p=0.865$; day $12: \mathrm{F}_{(4,70)}=1.096, p=0.366$; day $16: \mathrm{F}_{(4,70)}=3.071, \mathrm{P}=0.023$ (no significant effects found in Tukey's post-hoc test); Post oral arm length: day 4: $\mathrm{F}_{(4,70)}=1.553, p=0.196$; day 8: $\mathrm{F}_{(4,70)}=1.609, p=0.182$; day 12: $\mathrm{F}_{(4,70)}=1.962, p=0.110$; day $16: \mathrm{H}_{(4)}=8.190, p=0.085$; Figure $2 \mathrm{~b}$ and $\mathrm{d})$ or on rudiment lengths during the experimental period $\left(\mathrm{F}_{(4,60)}=0.617, p=0.652\right.$; Figure 3$)$.

\subsubsection{Larval shape}

Significant linear relationships were found across treatments for $P$. miliaris larval body lengths and larval body widths ( $p<0.05$, Table 4$)$ except for larvae reared at the highest density (4 larvae $\mathrm{mL}$ ${ }^{1} ; p>0.05$; Table 4). Therefore, the highest stocking density treatment (4 larvae $\left.\mathrm{mL}^{-1}\right)$ was excluded from regression analysis. Regression analysis demonstrated no significant effect of stocking density on larval body width ( $p>0.05$; Table 5). Significant linear relationships between larval body lengths and post oral arm lengths were found only in the 3 larvae $\mathrm{mL}^{-1}$ treatment (Table 4), with a progressive shortening of the post-oral arms.

Significant linear relationships were found across treatments in P. lividus $(p<0.05$; Table 4). Regression analysis showed no significant effect of stocking density on the relationship between larval body length and larval body width ( $p>0.05$; Table 5). Significant linear relationships between larval body length and post oral arm lengths were seen across all treatments ( $p<0.05$; Table 4$)$. Paracentrotus lividus larvae reared at 2 larvae $\mathrm{mL}^{-1}$ had lower post oral arm lengths relative to body size ratios in comparison to the lowest density treatments $\left(1\right.$ larvae $\left.\mathrm{mL}^{-1}\right)(p<0.05$; Table 5$)$ reflecting an increase in larval body length and a reduction in post oral arm length. This irregular development may be caused by external factors, such as differing larval development speeds between treatments which are more subtle than the development stages recorded above.

\subsection{Displacement trials}

\subsubsection{Psammechinus miliaris}

No significant differences in survival or development were found between the low density control larvae $\left(1 \mathrm{~mL}^{-1}\right)$ and the displacement treatment (D) across the experimental period (day 2: $\mathrm{F}_{(4,10)}$ $=1.351, p=0.318$; day $4: \mathrm{H}_{(4)}=4.633, p=0.327$; day $7: \mathrm{H}_{(4)}=0.645, p=0.567$; day 10: $\mathrm{F}_{(4,10)}=0.140$, $p=0.964 ;$ day 13: $\mathrm{F}_{(4,10)}=1.082, p=0.416$; day 16: $\mathrm{F}_{(4,10)}=2.025, p=0.167$; Figure 4a; Tables 2 and $3)$.

From day 8 until the end of the experimental period, larval lengths and post oral arm lengths for low stocking density larvae $\left(1 \mathrm{~mL}^{-1}\right)$ were significantly larger than the displacement treatment $(\mathrm{D}$; larval lengths: day 8: $\mathrm{F}_{(4,70)}=10.782, p<0.001$; day $12: \mathrm{F}_{(4,70)}=25.941, p<0.001$; day 16: $\mathrm{F}_{(4,70)}=$ 
19.588, $p<0.001$; post oral arm lengths: day 8: $\mathrm{F}_{(4,63)}=19.671, p<0.001$; day $12: \mathrm{H}_{(4)}=42.929, p<$

\section{4. Discussion} respectively). 0.001; day 16: $\mathrm{H}_{(4)}=32.989, p<0.001$; Figure 2a and c). However rudiment size was significantly similar between the low density control larvae $\left(1 \mathrm{~mL}^{-1}\right)$ and the displacement treatment $\left(\mathrm{D} ; \mathrm{F}_{(4,69)}=\right.$ 6.565, $p<0.001$ (no significant effects found in Tukey's post-hoc test); Figure 3a).

Regression analysis demonstrated no significant effect of the low stocking density control $\left(1 \mathrm{~mL}^{-1}\right)$ or the displacement treatment (D) on larval body width $(p>0.05$; Table 5) or between larval body lengths and post oral arm lengths ( $p>0.05$; Table 4$)$.

\subsubsection{Paracentrotus lividus}

No significant differences in survival were found between the low density control larvae $\left(1 \mathrm{~mL}^{-}\right.$ ${ }^{1}$ ) and the displacement treatment (D) across the experimental period (day 2: $\mathrm{F}_{(4,10)}=0.748, p=0.581$; day 4: $\mathrm{F}_{(4,10)}=2.068, p=0.160$; day $7: \mathrm{H}_{(4)}=3.833, p=0.429$; day $10: \mathrm{F}_{(4,10)}=1.082, p=0.416$; day 13: $\mathrm{H}_{(4)}=8.315, p=0.081$; day $16: \mathrm{H}_{(4)}=0.048, \mathrm{P}=0.048$ (no significant effects found in Tukey's post-hoc test); Figure $4 \mathrm{~b}$; Tables 2 and 3 ).

On day 16 , larval lengths in the low density control larvae $\left(1 \mathrm{~mL}^{-1}\right)$ were significantly larger than the displacement treatment $\left(D ; F_{(4,70)}=3.071, P=0.023\right.$; Figure $\left.2 b\right)$. Post oral arm and rudiment lengths were significantly similar between these treatments across the experimental period (post oral arms: day 4: $\mathrm{F}_{(4,70)}=1.553, p=0.196$; day $8: \mathrm{F}_{(4,70)}=1.609, p=0.182$; day $12: \mathrm{F}_{(4,70)}=1.962, p=0.110$; day 16: $\mathrm{H}_{(4)}=8.190, p=0.085$; Figure 2; rudiment length: $\mathrm{F}_{(4,60)}=0.617, p=0.652$; Figures $2 \mathrm{~d}$ and $3 \mathrm{~b}$

A significant linear relationship was not found between $P$. lividus larval body lengths and larval body widths in the density change experiment ( $\mathrm{D} ; p>0.05$; Table 4$)$. Therefore, a regression analysis was not assessed for these morphometrics.

Significant linear relationships between larval body length and post oral arm lengths were seen across both treatments ( $p>0.05$; Table 4$)$. Regression analysis demonstrated no significant effect of the low stocking density control $\left(1 \mathrm{~mL}^{-1}\right)$ or the displacement treatment (D) on larval body width $(p>$ 0.05; Table 5) or between larval body lengths and post oral arm lengths ( $\mathrm{p}>0.05$; Table 4).

\subsection{Psammechinus miliaris}

This study shows that stocking larvae at low densities of 1 larvae $\mathrm{mL}^{-1}$ produce the best quality larvae reflected by large larval and rudiment sizes. This result agrees with findings of Azad (2012) and Buitrago et al. (2005) who proposed that a stocking density of $1 \mathrm{~mL}^{-1}$ is also best for Strongylocentrotus purpuratus and Lytechinus variegatus respectively. This study also demonstrates that stocking $P$. miliaris larvae at 2 larvae $\mathrm{mL}^{-1}$ for a large part of the cultivation process (up to day 12) produces similarly performing larvae to those stocked at $1 \mathrm{~mL}^{-1}$. Although at this density the rudiment size was not significantly larger than counterparts stocked at higher densities (e.g. 3 and 4 larvae $\mathrm{mL}^{-1}$ ), it was 
similar in size to rudiments within low density $\left(1 \mathrm{~mL}^{-1}\right)$ larvae. This contrasts with Azad et al. (2012) who showed that larvae of $S$. purpuratus stocked at $2 \mathrm{~mL}^{-1}$ had significantly lower survival and growth relative to counterparts reared at a lower density of $1 \mathrm{~mL}^{-1}$, indicating that the latter species is likely to be more sensitive in cultivation than P. miliaris.

Stocking P. miliaris larvae at higher densities $\left(3\right.$ or $\left.4 \mathrm{~mL}^{-1}\right)$ did not affect survival or abnormal development. However, these densities did result in stunted growth leading to the development of smaller rudiments. Our data show that previous developmental stages (e.g. number of arms) were not impacted, therefore the smaller rudiment sizes were most likely due to stunted growth rather than developmental delays. Shorter post-oral arm lengths were observed within these high stocking densities which can indicate overabundant food supplies (Fenaux, 1994; Kelly et al. 2000) but food supplies were controlled across all treatments and therefore unlikely to be the cause of this stunted growth. No significant level of malnourishment was observed either, illustrating that these high stocking density cultures had sufficient food supplies further supporting the notion that food supply was not the cause of the stunted growth (Kelly et al. 2000; Liu et al. 2007). Buitrago et al. (2005) showed that larval morphological changes occur within high stocking densities, even with appropriate controlled food rations. Therefore, the morphological changes observed for $P$. miliaris stocked at high densities of 3 and 4 larvae $\mathrm{mL}^{-1}$ are likely to be density driven.

It is unknown how these morphological differences are caused, given that no significant effects on abnormal developments were observed. It could be that interactions were increasing levels of stress in larvae that in turn impacted metabolism, diverting energy away from somatic growth (Forsythe \& Heaukelem, 1987). Alternatively, increased levels of metabolically derived carbon dioxide, and therefore a reduced quality of seawater, may have caused lower growth rates, a phenomenon observed in ocean acidification studies (e.g. Azad et al., 2010; Suckling et al., 2014a). Therefore, impacts on the seawater carbonate chemistry would require more focus in future stocking density trials.

The performance of $P$. miliaris within the density change experiment was encouraging, where larvae were initially reared at a high density of 3 larvae $\mathrm{mL}^{-1}$ and then transferred to a lower density of 1 larvae $\mathrm{mL}^{-1}$. These larvae, at the end of the experimental period, had similar survival rates and rudiment lengths to those reared at low density $\left(1 \mathrm{~mL}^{-1}\right)$ despite a smaller size. This indicates that a density change approach to larval rearing may be a viable option in large scale cultivation of $P$. miliaris as rudiment development is key to metamorphosis into a competent juvenile (Gosselin \& Jangoux, 1998).

\subsection{Paracentrotus lividus}

Paracentrotus lividus appeared to be more resilient towards cultivation at higher stocking densities when compared with $P$. miliaris. Survival, development and morphological performances were all similar between larvae stocked at 1,2,3 and 4 larvae $\mathrm{mL}^{-1}$, in direct contrast with observations from other echinoid species (Azad, 2012; Buitrago et al. 2005). Although not a statistically significant 
340 result, it is worth noting from a cultivation perspective that the survival of $P$. lividus larvae reared under

341 the higher stocking density of 4 larvae $\mathrm{mL}^{-1}$ was approximately $25 \%$ lower than controls which may

342 have influence on aquaculture approaches.

343 Similarly to $P$. miliaris, the displacement of larvae from a high (3 larvae $\left.\mathrm{mL}^{-1}\right)$ to low stocking

344 density $\left(1 \mathrm{~mL}^{-1}\right.$; D) showed benefits to larval success and rearing effort when directly compared to

345 larvae continuously reared at low control stocking densities $\left(1 \mathrm{~mL}^{-1}\right)$. By the end of the experimental

346 period survival and rudiment sizes were similar despite smaller larval sizes found in displacement

347 larvae. Similar to our cautionary comment above, although not a statistically significant result, it is

348 worth noting that the survival of $P$. lividus larvae displaced from 3 to 1 larvae $\mathrm{mL}^{-1}$ was approximately

$34930 \%$ lower than controls which may have influence on aquaculture approaches.

350

351

352

\subsection{Conclusions}

Psammechinus miliaris is clearly best cultured at a density of 1 larvae $\mathrm{mL}^{-1}$ to achieve largest larval and rudiment sizes. The performance of P. lividus was similar across all densities of 1, 2, 3 and 4 larvae $\mathrm{mL}^{-1}$, making this species somewhat more appealing in intensive cultivation efforts. However, it must be noted that survival of high stocked larvae (4 larvae $\mathrm{mL}^{-1}$ ) after 16 days was notably (but not significantly) $25 \%$ lower than those reared at lower densities of 1 and 2 larvae $\mathrm{mL}^{-1}$. Displacing larvae from a high density of $3 \mathrm{~mL}^{-1}$ to a lower density of $1 \mathrm{~mL}^{-1}$ at day 13 is a viable option for both species if required by hatchery operators. However, it must be noted that survival of the displaced P. lividus larvae after 16 days was notably (but not significantly) $30 \%$ lower than those reared at a lower density of 1 larvae $\mathrm{mL}^{-1}$. This information is likely to be important for commercial hatcheries looking to utilise higher stocking densities during the larval rearing process. Responses to fixed stocking densities differed across the two species highlighting a need to take these approaches across a wider range of commercially important species. Establishing the optimum and efficient larval stocking densities for marketable species of sea urchins is crucial to the development of commercials scale hatcheries (Azad et al., 2010). This need is ever increasing in importance with natural fisheries facing over exploitation and climate change challenges (Grosjean et al., 1998; Suckling et al., 2015). 


\section{Acknowledgements}

The authors would like to thank Stefano Carboni (University of Stirling), Tim Attack and Rossamy Waring (Ardtoe) for the provision of Paracentrotus lividus broodstock and Lars Brunner (Scottish Association for Marine Science) for access to temporary holding facilities. This study was generated as part of the Postgraduate MSc programme in the host institution. The authors would also like to thank the anonymous Reviewers for their constructive comments.

\section{References}

Azad, K.A., Pearce, C.M. and McKinley, S. (2012). Influence of stocking density and temperature on early development and survival of the purple sea urchin, Strongylocentrotus purpuratus (Stimpon, 1857). Aqua. Res. 43: pp. 1577-1591.

Azad, K.A., McKinley, S. and Pearce, C.M. (2010) Factors influencing the growth and survival of larval and juvenile echinoids. Rev. Aquaculture 2: pp. 121-137.

Boudrouresque, C.F. and Velaque, M. (2007) Ecology of Paracentrotus lividus In: Lawrence, J.M. (Ed.) Edible sea urchin biology and ecology. Elsevier, Amsterdam, the Netherlands pp. 243-285.

Buitrago, E., Lodeiros, C., Lunar, K., Alvarado, D., Indorf, F., Frontadom, K., Moreno, P. and Zpoa, V. (2005) Mass production of competent larvae of the sea urchin Lytechinus variegatus (Echinodermata: Echinoidea). Aqua. Intern. 13: pp. 359-367.

Carboni, S., Kelly, M.S., Hughes, A.D., Vignier, J., Atack, T. and Migaud, H. (2014) Evaluation of flow through culture technique for commercial production of sea urchin (Paracentrotus lividus) larvae. J. Aqua. Res. 45: pp. 768-772.

Cho, C., Hynes, J., Wood, K. ad Yoshida, H. (1994) Development of high-nutrient-dense, low pollution diets and prediction of aquaculture wastes using biological approaches. Aquaculture 124: pp. 283-305.

Cook, E.J., Kelly M.S. and McKenzie J.D. (1998) Gonad development and somatic growth in the green sea urchin. Psammechinus miliaris fed artificial and natural diets. J. Shellfish. Res. 17: pp. 1549-1555.

Dytham, C. (1999) Choosing and using statistics, A biologist's guide, $3^{\text {rd }}$ Edition. Wiley-Blackwell, Oxford. 298p. 
Fenaux, L., Cellariom C. and Etienne, M. (1985) Variations in the ingestion rate of algal cells with morphological development of larvae of Paracentrotus lividus (Echinodermata, Echinoiddea) Mar. Ecol. Prog. Ser. 24: pp. 161-165.

Fenaux, L., Strathmann, M.F. and Strathmann, R.R. (1994) Five tests of food-limited growth of larvae in coastal water by comparisons of rates of development and form of echinoplutei. Limnol. Oceaogr. 39: pp. 84-98.

Fernandez, C.M. and Caltagirone, A. (1994) Growth rate of adult Paracentrotus lividus in a lagoon environment: the effect of different diet types. In:David, B., Guille, A., Feral, J.P., Roux, M. (Eds.) Echinoderms Through Time. Balkema, Rotterdam: pp. 655-660

Forsythe, J.W., Lee, P., Walsh, L. and Clark, T. (2002). The effects of crowding on the European cuttlefish, Sepia officinalis Linnaeus, 1758 reared at two temperatures. J. Exp. Mar. Biol. Ecol. 269: pp. 173-185.

Forsythe, J.W. and Van Heukelem, W.F. (1987). Growth. In: (Boyle, P.R. ed.) Cephalopod life cycles. Vol. II. Comparative Reviews. Academic Press, London, pp. 135-156.

Fujisawa, H. (1989). Differences in temperature dependence of early development of sea urchins with different growing seasons. Biol. Bull. 176: pp. 96-102.

Gomes, L.C., Baldisserotto, B. and Senhorini, J.A. (2000) Effect of stocking density on water quality, survival and growth of larvae of the matrinx-over-tilde Bryon cephalus (Characidae), in ponds. Aquaculture 183: pp. 73-81.

Gosselin, P. and Jangoux, M. (1998) From competent larva to exotrophic juvenile: a morphofunctional study of the perimetamorphic period of Paracentrotus lividus (Echinodermata, Echinoida) Zoomorph. 118: pp. 31-43.

Grosjean, P., Sperlet, C., Gosselia, P., Vaitilingon, D. and Jangoux, M. (1998) Land based, closed-cycle echinoculture of Paracentrotus lividus (Lamarck)(Echinoidea: Echinodermata): A long-term experiment at pilot scale. J. Shellfish Res. 17: pp. 1523-1531.

Hinegardner, R.T. (1969) Growth and development of laboratory sea urchin. Biol. Bull. 137: pp.465475. 
de Jong-Westman, M., March, B.E. and Carfoot, T.H. (1995) The effect of different nutrient

443 formulations in artificial diets on the gonad growth of the sea urchin Strongylocentrotus droebachiensis.

444 Can. J. Zool. 73: pp. 1495-1502.

Kelly, M.S., Brodie, C.C. and McKenzie, J.D. (1998) Somatic and gonadal growth of the sea urchin Psammechinus miliaris (Gmelin) maintained in polyculture with the Atlantic salmon. J. Shellfish Res. 17: pp. 1557-1562.

Kelly, M.S., Hunter, A.J., Scholfield, C.L. and McKenzie, J.D. (2000) Morphology and survivorship of larval Psammechinus miliaris (Gmelin) (Echinodermata: Echinoidea) in response to varying food quantity and quality. Aquaculture 183: pp. 223-240.

Leighton, P. (1995) Contributions towards the development of echinoculture in North Atlantic waters with particular reference to Paracentrotus lividus (Lamarck) PhD Thesis: National University of Ireland

Li, L. and Li, Q. (2010) Effects of stocking density, temperature and salinity on larval survival and growth of the red race of the sea cucumber Apostichopus japonicas (Selenka). Aquacult. Int. 264: pp. 263-278.

460

Liu, H. and Chang, Y-q. (2015) Sea urchin aquaculture in China. In: (Brown, N. and Eddy, S. eds.) Echinoderm Aquaculture. Wiley Blackwell, New Jersey, pp. 127-146.

463

Liu, H., Kelly, M.S., Cook, E.J., Black, K., Orr, H., Zhu, J.X. and Dong, S.L (2007) The effect of diet type on growth and fatty-acid composition of sea urchin larvae, I. Paracentrotus lividus (Lamarck, 1816) (Echinodermata). Aquaculture 264: pp. 247-262.

Martin, J.L.M., Veran, Y., Guelorget, O. and Pham, D. (1998) shrimp rearing: stocking density, growth, impact on sediment, waste output and their relationships studied through the nitrogen budget in rearing

McEdward, L. and Herrera, J. (1999) Body form and skeletal morphometrics during larval development of the sea urchin Lythechinus variegatus Lamarck. J. Exp. Mar. Biol. Eco. 232: pp. 151-176.

Okazaki, K. (1960) Skeleton formation of sea urchin larvae II. Organic matrix of the spicule. 

(1)

Paspatis, M., Boujard, T., Maragoudaki, D., Blanchard, G., Kentouri, M., (2003) Do stocking density and feed reward level affect growth and feeding of self-fed juvenile European sea bass? Aquaculture 216: pp. 103-113.

Siikavuopio, S.I., Dale, T. and Mortensen, A., (2007). The effects of stocking density on gonad growth, survival and feed intake of adult green sea urchin (Strongylocentrotus droebachiensis). Aquaculture. $262,78-85$.

Sokal, R.R. and Rohlf, J.F. (1995) Biometry $3^{\text {rd }}$ edition. Freeman and Co. New York.

Steffánsson, G., Kristinsson, H., Ziemer, N., Hannon, C., James, P. (2017). Markets for sea urchins: A review of global supply and markets. Icelandic Food \& Biotech R\&D Report. ISSN: 1670-7192.

Suckling, C.C., Clark, M.S., Beveridge, C., Brunner, L., Hughes, A.D., Harper, F.M., Cook, E.J., Davies, A.J. and Peck, L.S. (2014b) Experimental influence of pH on the early life-stages of sea urchins II: increasing parental exposure times gives rise to different resources. Invert. Repro. Develop. 58: pp. $161-175$.

Suckling, C.C., Clark, M.S., Peck, L.S. and Cook, E.J. (2014a) Experimental influence of pH on the early life-stages of sea urchins I; different rates of introduction give rise to different responses Invert. Repro. Develop. 58: pp.148-159.

Suckling, C.C., Clark, M.S., Richard, J., Morley, S.A., Thorne, M.A.S., Harper, E.M., Peck, L.S. (2015). Adult acclimation to combined temperature and $\mathrm{pH}$ stressors significantly enhances reproductive outcomes compared short-term exposures. J. Anim. Ecol. 84: pp. 773-784.

Suckling, C.C., Symonds, R.C., Kelly, M.S. and Young, A.J. (2011) The effect of artificial diet on gonad colour and biomass in the edible sea urchin Psammechinus miliaris. Aquaculture 318: pp. 336342.

Symonds, R.C., Kelly, M.S., Suckling, C.C., Young, A.J. 2009. Carotenoids in the gonad and gut of the edible sea urchin Psammechinus miliaris. Aquaculture 288: pp. 120-125. 2 3 4 


\section{List of Tables}

516

517 Table 1. Temperature $\left({ }^{\circ} \mathrm{C}\right)$, salinity (psu) and nitrate levels (ppm) of Psammechinus miliaris and 518 Paracentrotus lividus rearing tanks. Larvae were raised at 1, 2, 3 and 4 larvae $\mathrm{mL}^{-1}$ plus an additional 519 culture where larvae were transferred from densities of 3 larvae $\mathrm{mL}^{-1}$ to 1 larvae $\mathrm{mL}^{-1}$ on day 13 (D). 520 Table 1.

\begin{tabular}{lcccc}
\hline Species & Treatment & $\left({ }^{\circ} \mathrm{C}\right)$ & Salinity $(\mathrm{psu})$ & Nitrate $(\mathrm{ppm})$ \\
\hline Psammechinus & $1 \mathrm{~mL}^{-1}$ & $12.82 \pm 0.20$ & $33.92 \pm 0.12$ & $1.90 \pm 0.16$ \\
miliaris & $2 \mathrm{~mL}^{-1}$ & $12.51 \pm 0.17$ & $34.75 \pm 0.11$ & $3.19 \pm 0.29$ \\
& $3 \mathrm{~mL}^{-1}$ & $12.37 \pm 0.18$ & $34.56 \pm 0.13$ & $3.67 \pm 0.28$ \\
& $4 \mathrm{~mL}^{-1}$ & $12.25 \pm 0.18$ & $34.86 \pm 0.13$ & $4.52 \pm 0.41$ \\
& $\mathrm{D} \mathrm{mL}-1$ & $12.45 \pm 0.17$ & $34.87 \pm 0.13$ & $3.05 \pm 0.32$ \\
\hline Paracentrotus & $1 \mathrm{~mL}^{-1}$ & $11.60 \pm 0.06$ & $34.47 \pm 1.90$ & $1.90 \pm 0.15$ \\
lividus & $2 \mathrm{~mL}^{-1}$ & $11.23 \pm 0.05$ & $34.66 \pm 0.08$ & $2.52 \pm 0.15$ \\
& $3 \mathrm{~mL}^{-1}$ & $11.04 \pm 0.04$ & $34.78 \pm 0.08$ & $2.64 \pm 0.19$ \\
& $4 \mathrm{~mL}^{-1}$ & $10.85 \pm 0.04$ & $34.74 \pm 0.10$ & $3.19 \pm 0.22$ \\
& $\mathrm{D} \mathrm{mL}$ & & $34.84 \pm 0.09$ & $2.50 \pm 0.11$ \\
\hline
\end{tabular}


523 Table 2. Larval development stages (\% \pm SE) of Psammechinus miliaris and Paracentrotus lividus.

524 Larvae were raised at 1, 2, 3 and 4 larvae $\mathrm{mL}^{-1}$ plus an additional culture where larvae were transferred

525 from densities of 3 larvae $\mathrm{mL}^{-1}$ to 1 larvae $\mathrm{mL}^{-1}$ on day 13 (D). Differing letters as superscripts indicate

526 where significant differences occur between treatments for each sample day row. DF $=$ degrees of

527 freedom, Statistic $=$ statistical outcome, $\mathrm{P}=$ probability. NSD* indicates a Type II Error with a visual

528 inspection of the means and confidence intervals showing no significant differences (NSD).

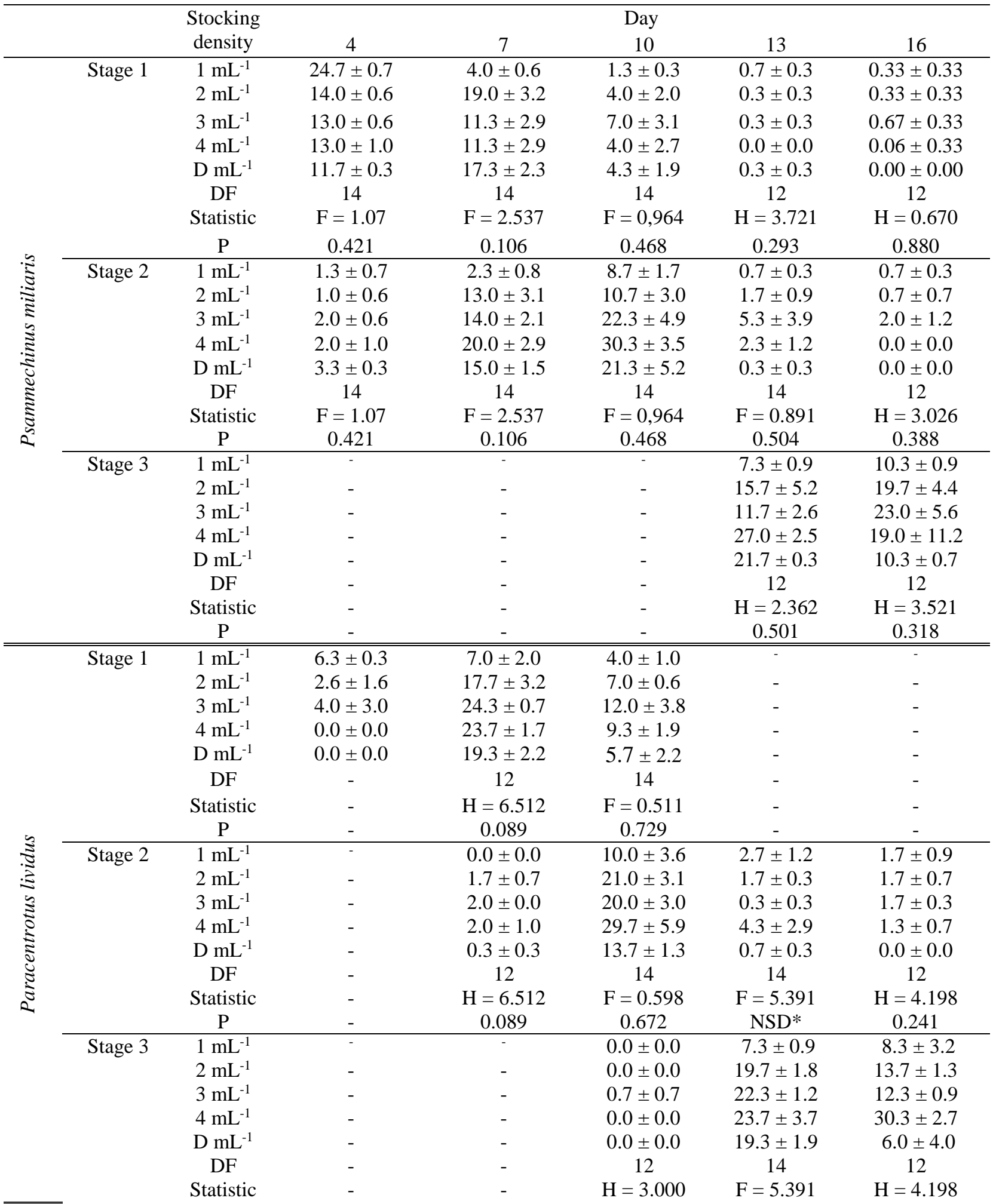


531 Table 3. Percentage of abnormally developed and malnourished larvae ( $\% \pm$ SE) of Psammechinus miliaris and Paracentrotus lividus. Larvae were raised at 1, 2, 3 and 4 larvae $\mathrm{mL}^{-1}$ plus an additional culture where larvae were transferred from densities of 3 larvae $\mathrm{mL}^{-1}$ to 1 larvae $\mathrm{mL}^{-1}$ on day 13 (D). Differing letters as superscripts indicate where significant differences occur between treatments. DF = degrees of freedom, Statistic $=$ statistical outcome, $\mathrm{P}=$ probability .

\begin{tabular}{|c|c|c|c|c|c|c|}
\hline & \multirow{2}{*}{$\begin{array}{l}\text { Stocking } \\
\text { density }\end{array}$} & \multicolumn{4}{|c|}{ Day } \\
\hline & & & 4 & 8 & 12 & 16 \\
\hline \multirow{16}{*}{ 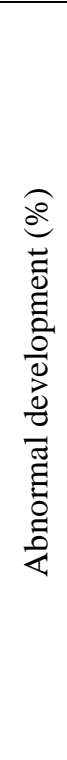 } & \multirow{8}{*}{$\begin{array}{l}\text { Psammechinus } \\
\text { miliaris }\end{array}$} & 1 & $6.7 \pm 0.1$ & $13.3 \pm 0.1$ & $13.3 \pm 0.1$ & $13.3 \pm 0.1$ \\
\hline & & 2 & $0.0 \pm 0.0$ & $13.3 \pm 0.1$ & $13.3 \pm 0.1$ & $40.0 \pm 0.1$ \\
\hline & & 3 & $0.0 \pm 0.0$ & $20.0 \pm 0.1$ & $53.3 \pm 0.1$ & $33.3 \pm 0.1$ \\
\hline & & 4 & $0.0 \pm 0.0$ & $6.7 \pm 0.03$ & $13.3 \pm 0.1$ & $53.3 \pm 0.1$ \\
\hline & & D & $0.0 \pm 0.0$ & $53.3 \pm 0.1$ & $20.0 \pm 0.1$ & $20.0 \pm 0.1$ \\
\hline & & DF & 14 & 14 & 14 & 14 \\
\hline & & Statistic & $\mathrm{H}=0.406$ & $F=2.700$ & $\mathrm{~F}=1.915$ & $\mathrm{~F}=1.374$ \\
\hline & & $\mathrm{P}$ & 0.452 & 0.092 & 0.185 & 0.310 \\
\hline & \multirow{8}{*}{$\begin{array}{l}\text { Paracentrotus } \\
\text { lividus }\end{array}$} & 1 & $46.7 \pm 0.1$ & $46.7 \pm 0.1^{\mathrm{a}}$ & $20.0 \pm 0.1$ & $0.0 \pm 0.0$ \\
\hline & & 2 & $46.7 \pm 0.1$ & $6.7 \pm 0.1^{\mathrm{ab}}$ & $6.7 \pm 0.1$ & $26.7 \pm 0.1$ \\
\hline & & 3 & $20.0 \pm 0.1$ & $26.7 \pm 0.1^{\mathrm{ab}}$ & $20.0 \pm 0.1$ & $33.3 \pm 0.1$ \\
\hline & & 4 & $46.7 \pm 0.1$ & $0.0 \pm 0.0^{\mathrm{b}}$ & $13.3 \pm 0.1$ & $33.3 \pm 0.1$ \\
\hline & & D & $53.3 \pm 0.1$ & $33.3 \pm 0.1^{\mathrm{ab}}$ & $26.7 \pm 0.1$ & $36.7 \pm 0.1$ \\
\hline & & DF & 14 & 14 & 14 & 14 \\
\hline & & Statistic & $\mathrm{F}=1.704$ & $\mathrm{H}=11.477$ & $\mathrm{~F}=0.538$ & $\mathrm{~F}=2.644$ \\
\hline & & $\mathrm{P}$ & 0.225 & 0.022 & 0.711 & 0.133 \\
\hline \multirow{16}{*}{ 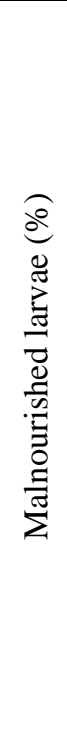 } & \multirow{8}{*}{$\begin{array}{l}\text { Psammechinus } \\
\text { miliaris }\end{array}$} & 1 & $0.0 \pm 0.0$ & $6.7 \pm 0.1$ & $0.0 \pm 0.0$ & $13.3 \pm 0.1$ \\
\hline & & 2 & $13.3 \pm 0.1$ & $0.0 \pm 0.0$ & $0.0 \pm 0.0$ & $0.0 \pm 0.0$ \\
\hline & & 3 & $0.0 \pm 0.1$ & $0.0 \pm 0.0$ & $0.0 \pm 0.0$ & $0.0 \pm 0.0$ \\
\hline & & 4 & $13.3 \pm 0.1$ & $13.3 \pm 0.1$ & $6.7 \pm 0.1$ & $13.3 \pm 0.1$ \\
\hline & & D & $0.0 \pm 0.0$ & $13.3 \pm 0.1$ & $0.0 \pm 0.0$ & $6.7 \pm 0.1$ \\
\hline & & DF & 14 & 14 & 14 & 14 \\
\hline & & Statistic & $\mathrm{H}=5.709$ & $\mathrm{H}=4.056$ & $\mathrm{H}=4.000$ & $H=4.056$ \\
\hline & & $\mathrm{P}$ & 0.222 & 0.399 & 0.406 & 0.399 \\
\hline & \multirow{8}{*}{$\begin{array}{l}\text { Paracentrotus } \\
\text { lividus }\end{array}$} & 1 & $46.7 \pm 0.1$ & $46.7 \pm 0.1$ & $20.0 \pm 0.1$ & $0.0 \pm 0.0$ \\
\hline & & 2 & $46.7 \pm 0.1$ & $6.7 \pm 0.1$ & $6.7 \pm 0.1$ & $26.7 \pm 0.1$ \\
\hline & & 3 & $20.0 \pm 0.1$ & $26.7 \pm 0.1$ & $20.0 \pm 0.1$ & $33.3 \pm 0.1$ \\
\hline & & 4 & $46.7 \pm 0.1$ & $0.0 \pm 0.0$ & $13.3 \pm 0.1$ & $33.3 \pm 0.1$ \\
\hline & & D & $53.3 \pm 0.1$ & $33.3 \pm 0.1$ & $26.7 \pm 0.1$ & $30.0 \pm 0.1$ \\
\hline & & DF & 14 & 14 & 14 & 14 \\
\hline & & Statistic & $\mathrm{F}=2.146$ & $\mathrm{H}=4.056$ & $\mathrm{~F}=0.538$ & $\mathrm{~F}=0.382$ \\
\hline & & $\mathrm{P}$ & 0.149 & 0.399 & 0.711 & 0.816 \\
\hline
\end{tabular}


539 Table 4. Analysis of variance for linear regressions between larval body length with either larval body

540 width or post oral arm length, for Psammechinus miliaris and Paracentrotus lividus. Larvae were raised

541 at 1, 2, 3 and 4 larvae $\mathrm{mL}^{-1}$ plus an additional culture where larvae were transferred from densities of 3

542 larvae $\mathrm{mL}^{-1}$ to 1 larvae $\mathrm{mL}^{-1}$ on day 13 (D). Significant regressions are indicated by numbers in bold.

$543 \mathrm{DF}=$ degrees of freedom, $\mathrm{F}=\mathrm{F}$-statistic, $\mathrm{P}=$ probability.

\begin{tabular}{|c|c|c|c|c|c|c|c|}
\hline Species & Body shape metric & Treatment & Slope & $\mathrm{R}^{2}$ & DF & $\mathrm{F}$ & $P$ \\
\hline \multirow{10}{*}{$\begin{array}{l}\text { Psammechinus } \\
\text { miliaris }\end{array}$} & \multirow{5}{*}{ Larval body width } & 1 & -0.022 & 0.813 & 1,53 & 230.411 & $<0.001$ \\
\hline & & 2 & -0.021 & 0.528 & 1,55 & 61.548 & $<0.001$ \\
\hline & & 3 & -0.007 & 0.238 & 1,57 & 17.784 & $<0.001$ \\
\hline & & 4 & 0.014 & 0.064 & 1,58 & 3.944 & 0.052 \\
\hline & & $\mathrm{D}$ & -0.004 & 0.298 & 1,58 & 24.584 & $<0.001$ \\
\hline & \multirow{5}{*}{ Post oral arm length } & 1 & 0.020 & 0.022 & 1,50 & 1.102 & 0.299 \\
\hline & & 2 & 0.015 & 0.000 & 1,52 & 0.004 & 0.952 \\
\hline & & 3 & 0.019 & 0.090 & 1,54 & 5.361 & 0.024 \\
\hline & & 4 & 0.005 & 0.028 & 1,55 & 1.569 & 0.216 \\
\hline & & $\mathrm{D}$ & 0.010 & 0.004 & 1,55 & 0.209 & 0.650 \\
\hline \multirow{10}{*}{$\begin{array}{l}\text { Paracentrotus } \\
\quad \text { lividus }\end{array}$} & \multirow{5}{*}{ Larval body width } & 1 & 0.000 & 0.373 & 1,54 & 32.144 & $<0.001$ \\
\hline & & 2 & -0.006 & 0.602 & 1,58 & 87.698 & $<0.001$ \\
\hline & & 3 & -0.005 & 0.552 & 1,59 & 71.574 & $<0.001$ \\
\hline & & 4 & -0.013 & 0.705 & 1,58 & 138.403 & $<0.001$ \\
\hline & & $\mathrm{D}$ & -0.021 & 0.064 & 1,52 & 33.582 & 0.064 \\
\hline & \multirow{5}{*}{ Post oral arm length } & 1 & 0.000 & 0.382 & 1,54 & 33.403 & $<0.001$ \\
\hline & & 2 & -0.003 & 0.465 & 1,58 & 50.411 & $<0.001$ \\
\hline & & 3 & -0.001 & 0.327 & 1,58 & 28.228 & $<0.001$ \\
\hline & & 4 & -0.002 & 0.400 & 1,58 & 38.727 & $<0.001$ \\
\hline & & D & -0.001 & 0.335 & 1,52 & 26.220 & $<0.001$ \\
\hline
\end{tabular}


Table 5. Analysis of variance between stocking density on the a) larval body width and b) post oral arm length of Psammechinus miliaris and Paracentrotus lividus larvae. The covariate is larval body length and all data were log transformed. Significant treatment effects are indicated by numbers in bold. DF =

560 degrees of freedom, MS = mean square, $\mathrm{F}=\mathrm{F}$ statistic, $\mathrm{P}=$ probability.

\begin{tabular}{|c|c|c|c|c|c|}
\hline & Treatment & DF & MS & $\mathrm{F}$ & $P$ \\
\hline \multirow[t]{6}{*}{ Psammechinus miliaris } & Larval density & 4 & $<0.001$ & 0.620 & 0.610 \\
\hline & $\begin{array}{l}\text { Larval width covaried } \\
\text { with body length }\end{array}$ & 1 & 0.014 & 32.580 & $<0.001$ \\
\hline & Error & 285 & $<0.001$ & & \\
\hline & Larval density & 4 & 0.001 & 12.391 & $<0.001$ \\
\hline & $\begin{array}{l}\text { Post oral arm length } \\
\text { covaried with body length }\end{array}$ & 1 & 0.001 & 9.947 & 0.302 \\
\hline & Error & 367 & $<0.001$ & & \\
\hline \multirow[t]{6}{*}{ Paracentrotus lividus } & Larval density & 4 & $<0.001$ & 0.642 & 0.585 \\
\hline & $\begin{array}{l}\text { Larval width covaried } \\
\text { with body length }\end{array}$ & 1 & 0.015 & 69.354 & $<0.001$ \\
\hline & Error & 284 & $<0.001$ & & \\
\hline & Larval density & 4 & $<0.001$ & 5.999 & $<0.003$ \\
\hline & $\begin{array}{l}\text { Post oral arm length } \\
\text { covaried with body length }\end{array}$ & 1 & 0.002 & 123.881 & $<0.001$ \\
\hline & Error & 284 & $<0.001$ & & \\
\hline
\end{tabular}

561

562

563

564

565

566

567

568

569

570

571

572

573

574

575

576

577

578

579

580

581

582 
585 Figure 1. Mean ( $\pm 1 \mathrm{SE})$ survival of a) Psammechinus miliaris and b) Paracentrotus lividus raised at 586 stocking densities of 1, 2, 3 and 4 larvae $\mathrm{mL}^{-1}$.

a) Psammechinus miliaris

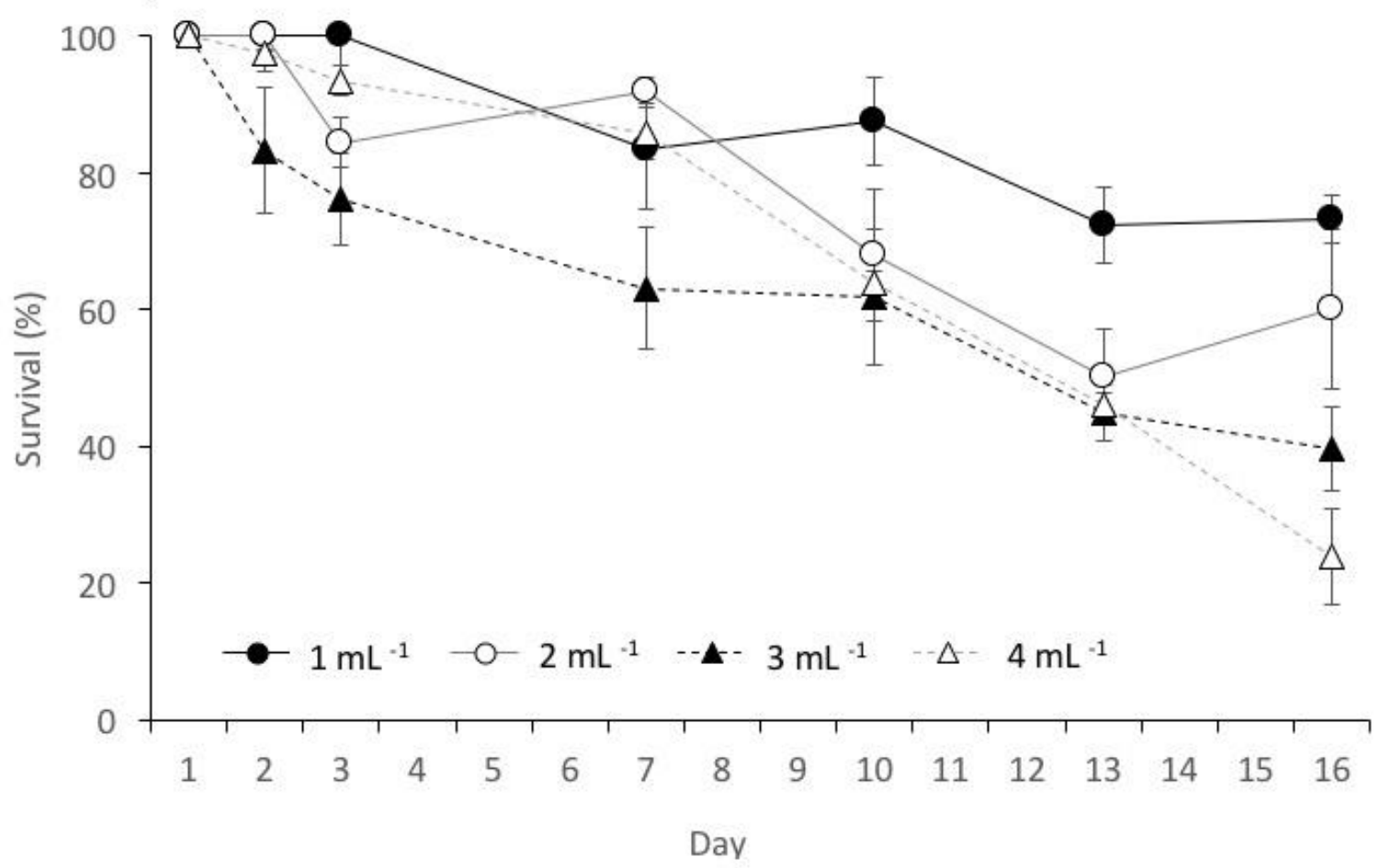

b) Paracentrotus lividus

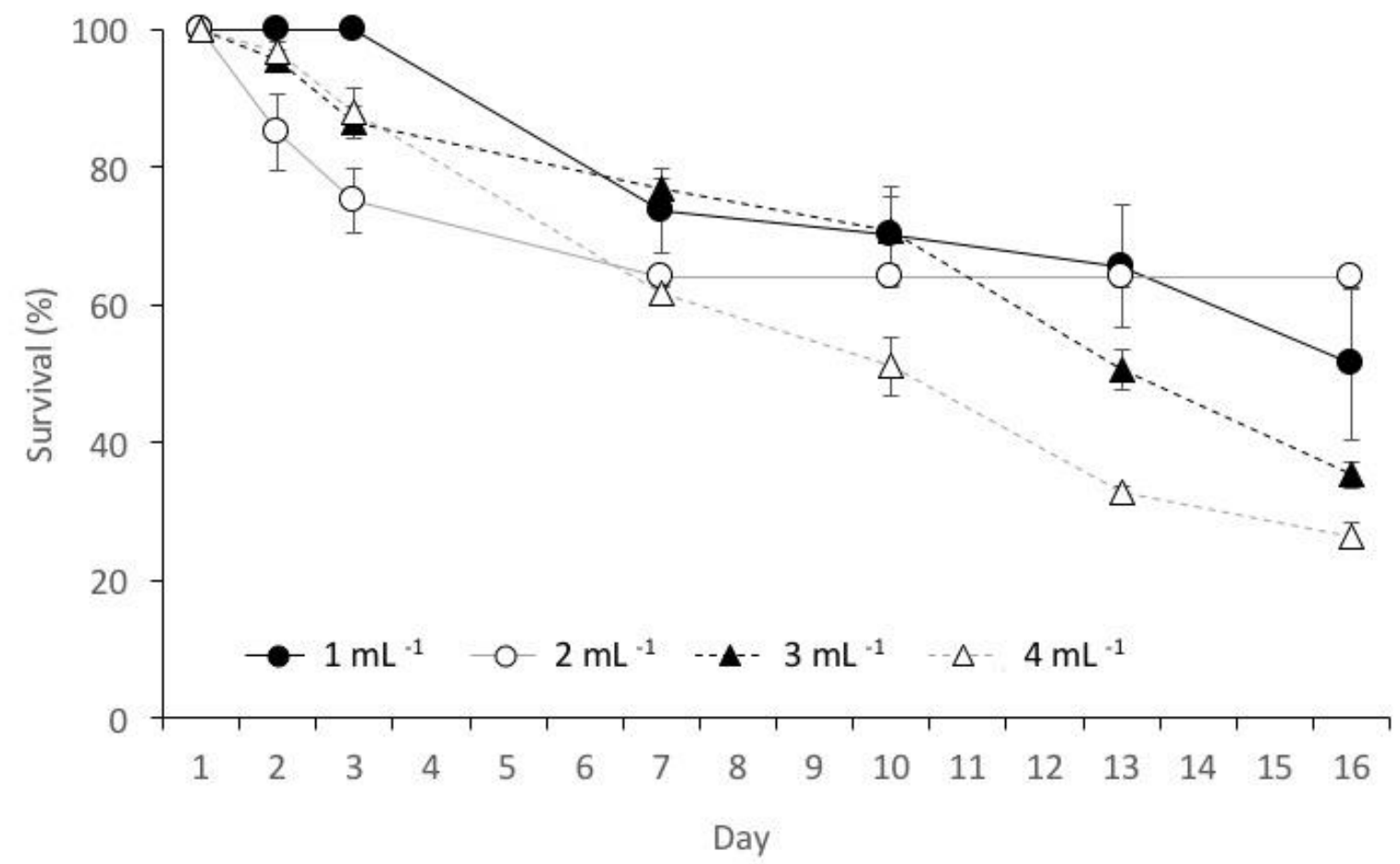


588 Figure 2. Morphological aspects of a) Psammechinus miliaris and b) Paracentrotus lividus; i) Larval 589 length, ii) Post oral arm length as recorded throughout the larval life span (days) raised at stocking 590 densities of 1, 2, 3 and 4 larvae $\mathrm{mL}^{-1}$ plus an additional culture where larvae were transferred from 591 densities of 3 larvae $\mathrm{mL}^{-1}$ to 1 larvae $\mathrm{mL}^{-1}$ on day 13 (D). Mean $( \pm 1 \mathrm{SE})$ values for pooled replicates $(n$ $592=15$, total $\mathrm{n}=45$ ) are presented.

Psammechinus miliaris

a)

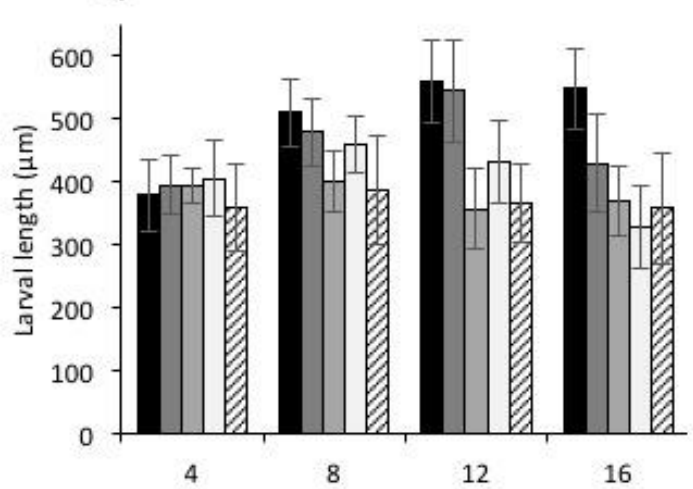

c)

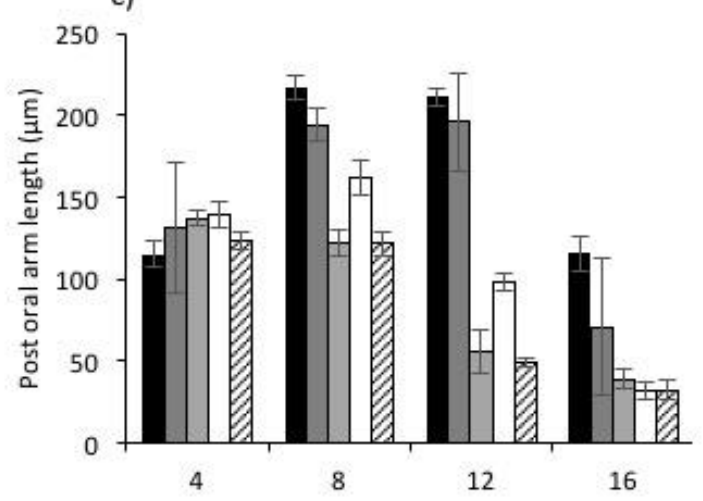

Paracentrotus lividus

b)

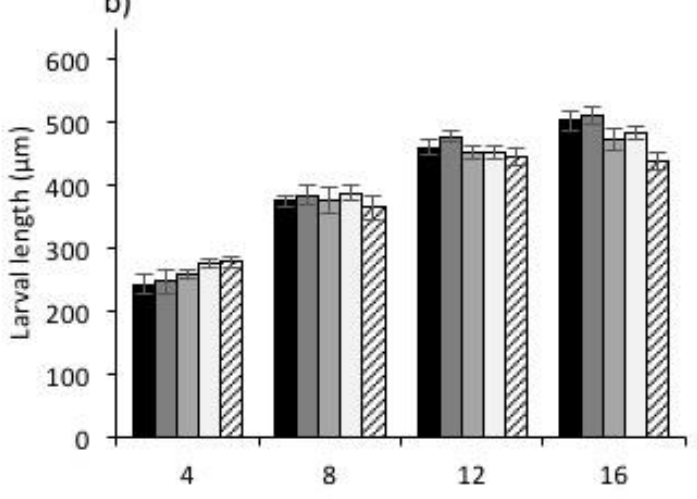

d)

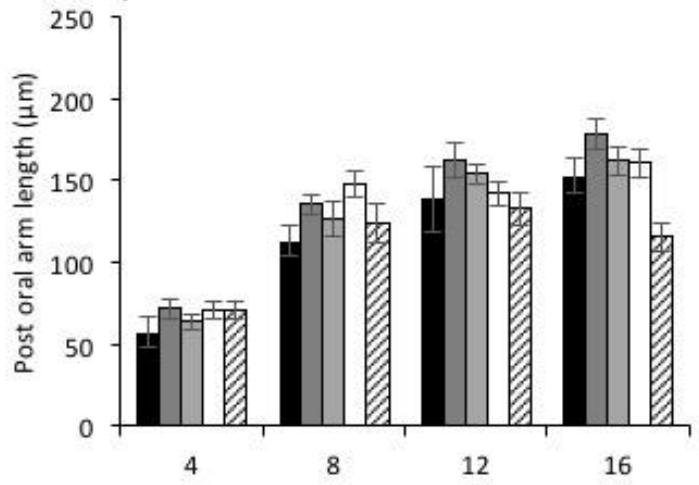

- $1 \mathrm{~mL}^{-1}$

ㅁ $2 \mathrm{~mL}^{-1}$

$3 \mathrm{~mL}^{-1}$

ㅁ. $4 \mathrm{~mL}^{-1} \boxminus \mathrm{D}$ 
594 Figure 3. Rudiment lengths of a) Psammechinus miliaris and b) Paracentrotus lividus; length as 595 recorded throughout the larval life span (days) raised at stocking densities of 1, 2, 3 and 4 larvae $\mathrm{mL}^{-1}$ 596 plus an additional culture where larvae were transferred from densities of 3 larvae $\mathrm{mL}^{-1}$ to 1 larvae mL$597{ }^{1}$ on day 13 (D). Mean $( \pm 1 \mathrm{SE})$ values for pooled replicates $(n=15$, total $\mathrm{n}=45)$ are presented.

a) Psammechinus miliaris

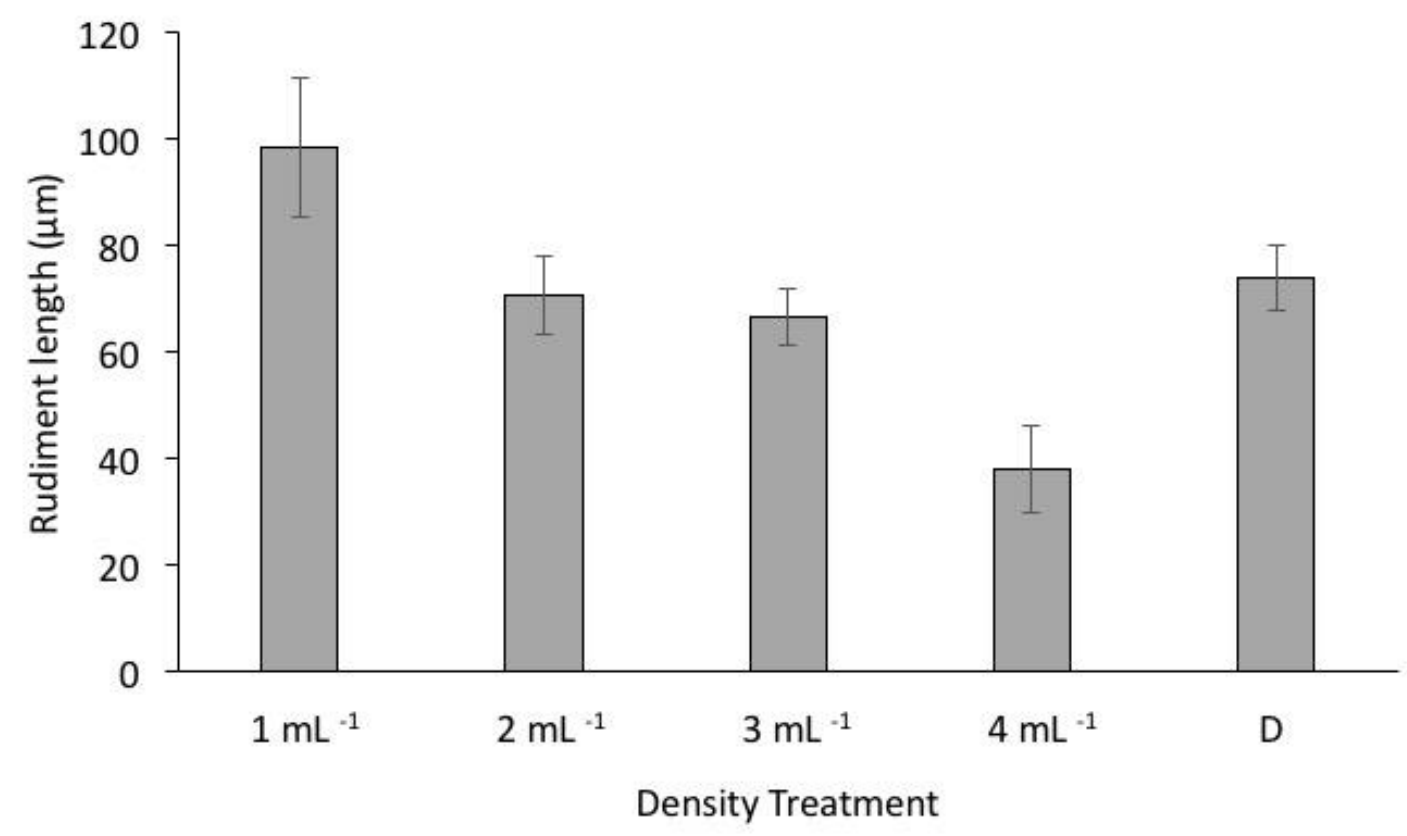

b) Paracentrotus lividus

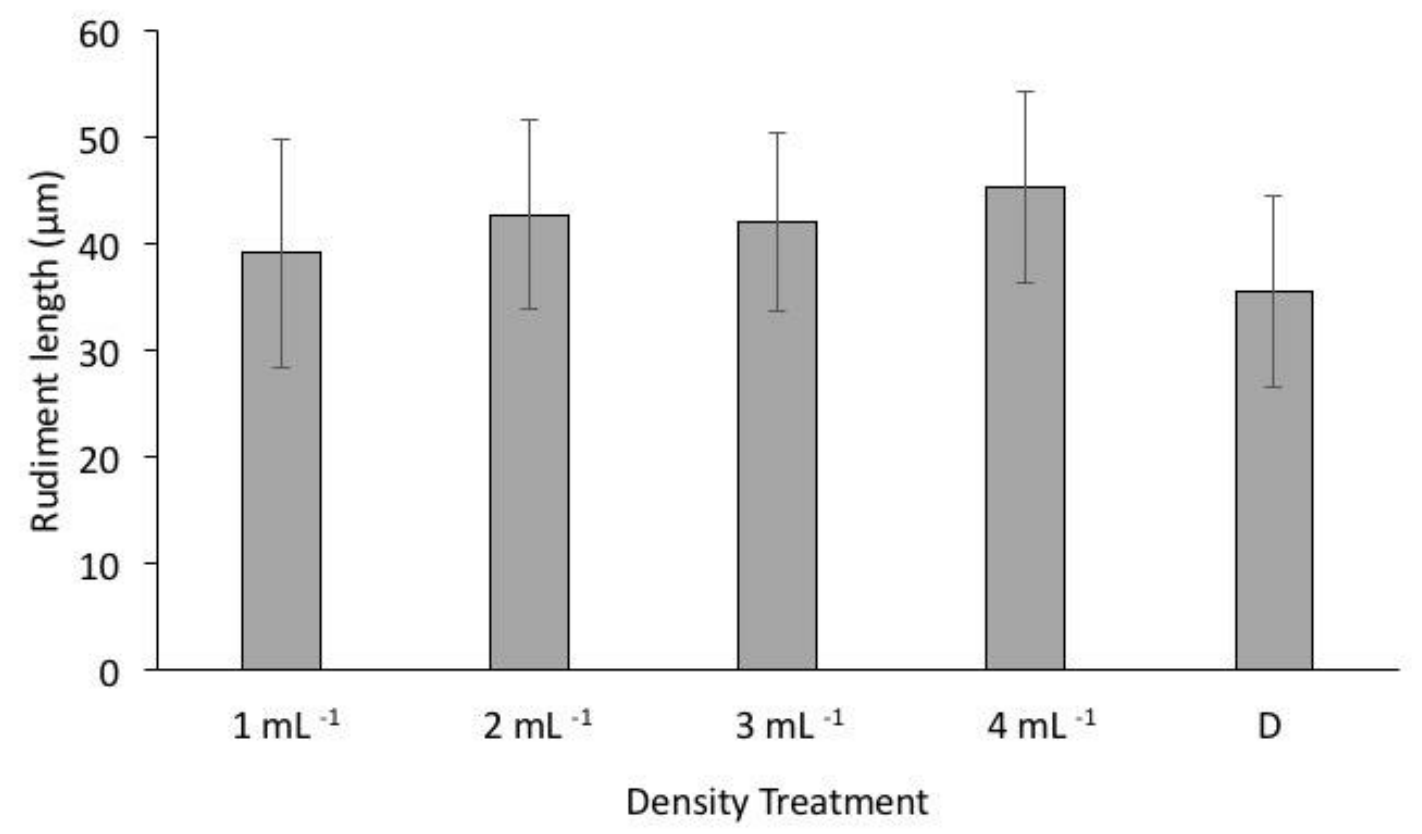


Figure 4. Mean ( $\pm 1 \mathrm{SE})$ survival of a) Psammechinus miliaris and b) Paracentrotus lividus raised at a 600 low control stocking density of 1 larvae $\mathrm{mL}^{-1}$ and larvae initially reared at a high density of $3 \mathrm{~mL}^{-1}$ and 601 then displaced to a low density of $1 \mathrm{~mL}^{-1}$ on day 13 (D).

a) Psammechinus miliaris

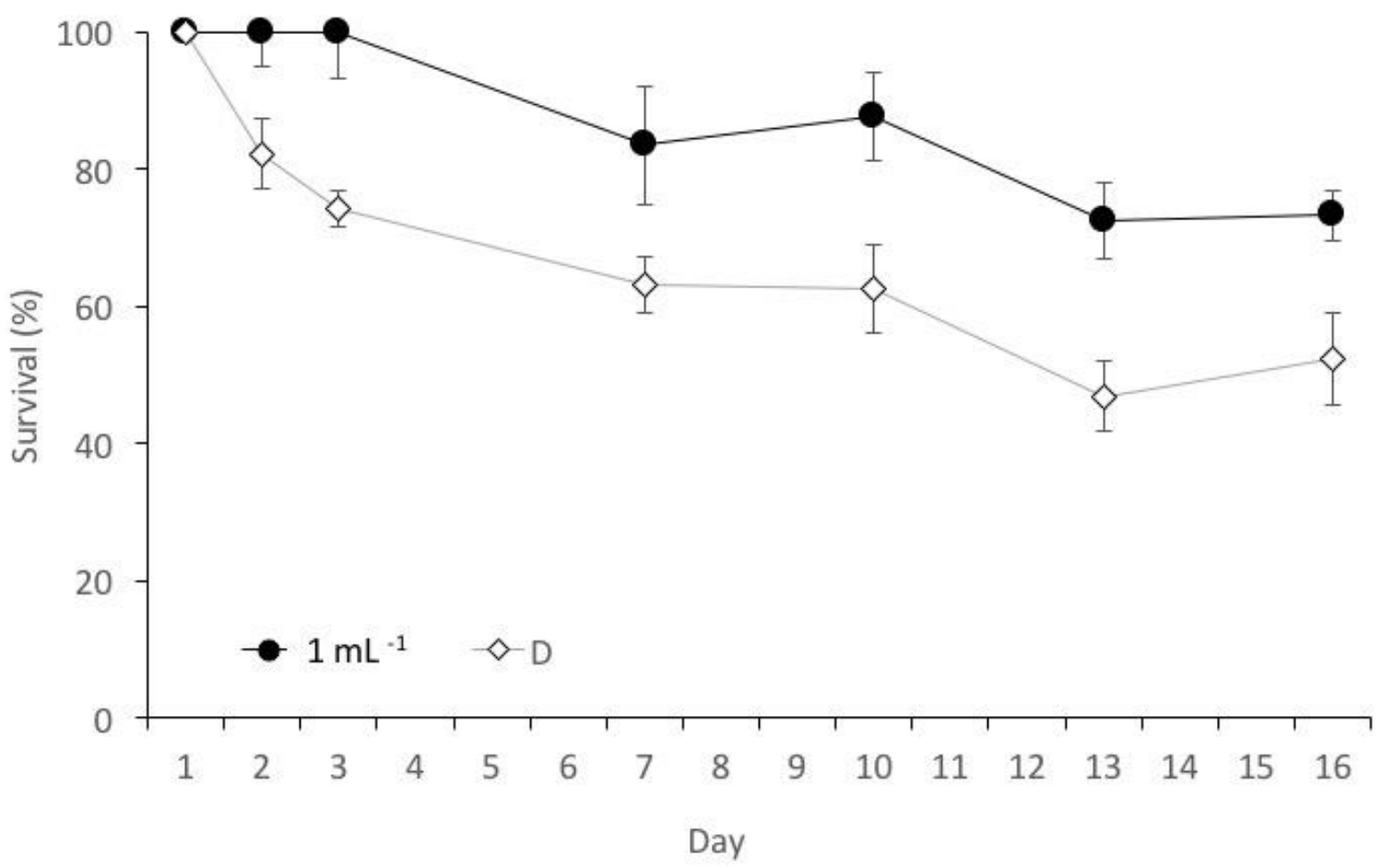

b) Paracentrotus lividus

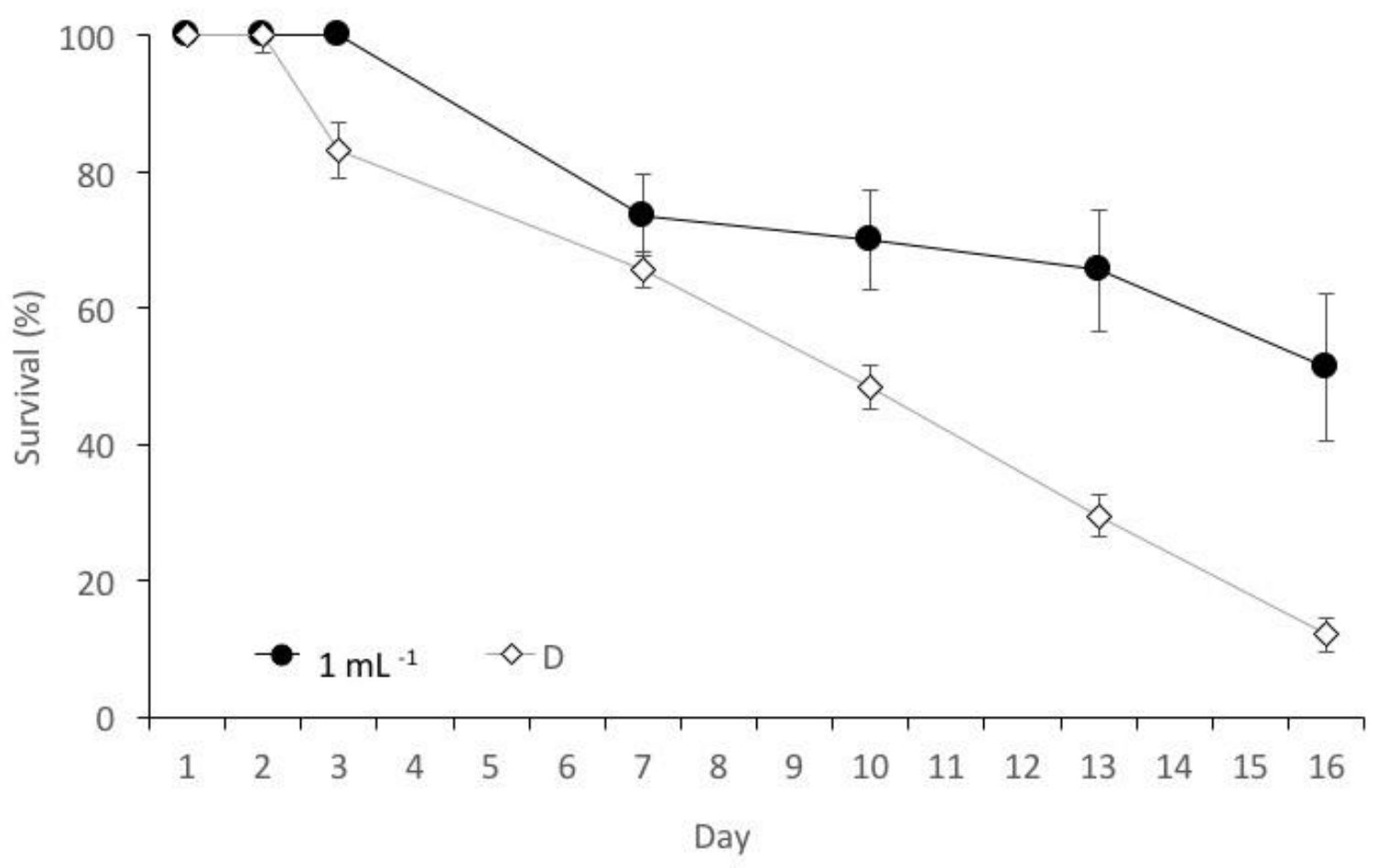

602 